\title{
Residual B Cell Function in Diabetic Children as Determined by Urinary C-peptide
}

\author{
J. Aurbach-Klipper ${ }^{1}$, R. Sharph-Dor ${ }^{1}$, L. G. Heding ${ }^{2}$, M. Karp ${ }^{1}$ and Z. Laron ${ }^{1}$ \\ ${ }^{1}$ Institute of Pediatric and Adolescent Endocrinology, Beilinson Medical Center, Petah Tikva and Sackler School of Medicine, \\ Tel Aviv University, Israel and ${ }^{2}$ Novo Research Institute, Bagsvaerd, Denmark
}

\begin{abstract}
Summary. C-peptide was determined in 24-h urine collections and in fasting plasma of 27 Type 1 (insulin-dependent) diabetic children (duration of disease 0-6 years) and in 11 matched normal children. Grouping the patients according to duration of disease from onset to 6 years, it was found that in the first year of disease the B cell reserve was a mean of $4.89 \pm 1.95$ pmol $\cdot \mathrm{mg}$ creatinine ${ }^{-1} \cdot 24 \mathrm{~h}^{-1}$ compared with a mean of $24.51 \pm 2.91 \mathrm{pmol} \cdot \mathrm{mg}^{-1} \cdot 24 \mathrm{~h}^{-1}$ in the control group. A further diminution was seen with increase in the duration of disease, until after 6 years when only traces of C-peptide could
\end{abstract}

be detected. There was a good correlation between the levels of plasma C-peptide and urinary C-peptide values as related to creatinine $(r=0.89 ; p=<0.001)$. In view of this, and since it is simpler and less traumatic to obtain frequent urine samples from children than it is to obtain blood samples, it was felt that the determination of urinary C-peptide constitutes a valuable tool in the evaluation of the diabetic child.

Key words: C-peptide, Type 1 diabetes, B cell reserve, children.
The evaluation of plasma C-peptide has come to be an accepted means for the assessment of $B$ cell reserve. Most investigators have used plasma samples for the determination of basal levels of C-peptide and the response to stimulation by a test meal or intravenous glucagon [1-6]. However, data on C-peptide values in 24-h urine collections are relatively scant [7-9]. We present the findings of a study on both urinary and plasma Cpeptide in 27 children with diabetes mellitus of varying duration (from $<1$ year to 6 years after the onset of the disease).

\section{Subjects and Methods}

The subjects comprise 27 diabetic patients, selected at random, who were between 5-17 years of age and who had been suffering from diabetes for periods ranging from shortly after onset to 6 years. For purposes of statistical analysis, these patients were divided into six groups in accordance with duration of the disease (up to 1 year and 2, $3,4,5$ and 6 years). Eleven children (aged $7-14$ years) served as control subjects. They had been referred for investigation of short stature and had been found to be in good health, with no endocrine abnormality, and body height between the third and tenth percentile.

Twenty-four hour urine samples were collected in plastic containers which were kept under refrigeration during the collection period. After volume measurement, an aliquot of the urine was adjusted to $\mathrm{pH} 7-8$ with $1 \mathrm{~N} \mathrm{NaOH}$ and kept frozen at $-20^{\circ} \mathrm{C}$ until assay. Blood samples, obtained after an overnight fast at the end of the collection period, were centrifuged and the plasma then frozen at $-20^{\circ} \mathrm{C}$ until assay. Immunoreactivity of C-peptide in urine and plasma was determined by the method of Heding [10] using the radioimmunoassay kit of Novo Laboratories, Copenhagen which is based on the single antibody technique (anti-synthetic human C-peptide guinea pig serum). The urine samples were diluted with $0.04 \mathrm{~mol} / 1$ phosphate buffer, the samples of the diabetic patients being assayed in three dilutions $(1: 5$, $1: 10,1: 50)$, whereas those of the healthy control subjects were assayed in five dilutions $(1: 10,1: 20,1: 50,1: 100,1: 200)$. The interassay variations, and the variations between the different dilutions were $<5 \%$. The sensitivity was up to $0.01 \mathrm{pmol} / \mathrm{ml}$.

\section{Results}

Figure 1 shows the mean ( \pm SEM) urinary C-peptide levels in the control group and in six groups of diabetic children. In the control group, values ranged from 16 to $39.7 \mathrm{pmol} \cdot \mathrm{mg}$ creatinine $\mathrm{e}^{-1} \cdot 24 \mathrm{~h}^{-1}$ with a mean of $24.51 \pm 2.91 \mathrm{pmol} \cdot \mathrm{mg}$ creatinine $\mathrm{c}^{-1} \cdot 24 \mathrm{~h}^{-1}$. Among the patients, those who were newly diagnosed or had diabetes for up to 1 year had a mean value of urinary Cpeptide which was approximately $20 \%$ that of the normal $\left(4.89 \pm 1.95 \mathrm{pmol} \cdot \mathrm{mg}\right.$ creatinine $\left.\mathrm{e}^{-1} \cdot 24 \mathrm{~h}^{-1}\right)$. In group 2 ( 2 years), the range of values was 1.88 $0.18 \mathrm{pmol} \cdot \mathrm{mg}$ creatinine $\mathrm{e}^{-1} \cdot 24 \mathrm{~h}^{-1}$ with a mean of 1.0 $\pm 0.29 \mathrm{pmol} \cdot \mathrm{mg}$ creatinine $\mathrm{e}^{-1} \cdot 24 \mathrm{~h}^{-1}$ and in the other groups there was a continuing trend towards diminution of the C-peptide, with only traces $(0.07-$ 


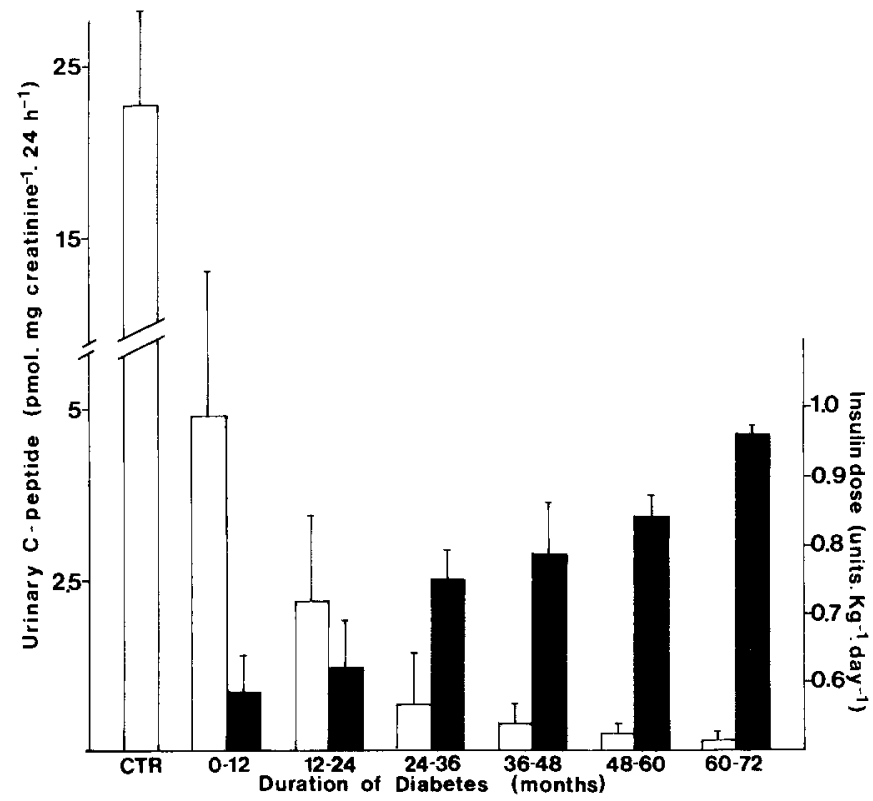

Fig. 1. Correlation between urinary C-peptide, insulin dose and duration of diabetes. $\square$ Urinary C-peptide; Insulin dose

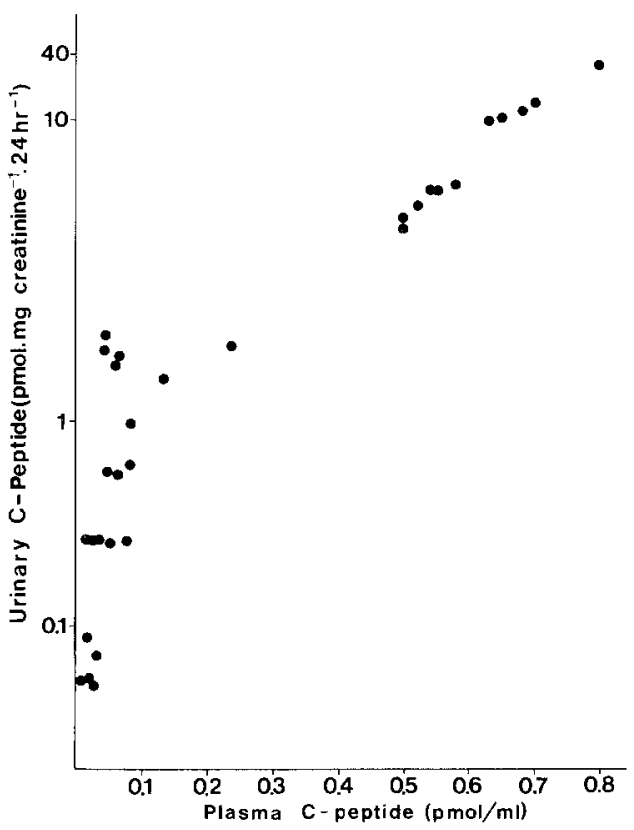

Fig. 2. Correlation between urinary and plasma C-peptide

$1.67 \mathrm{pmol} \cdot \mathrm{mg}$ creatinine $\mathrm{e}^{-1} \cdot 24 \mathrm{~h}^{-1}$; mean $0.117 \pm$ $0.001 \mathrm{pmol} \cdot \mathrm{mg}$ creatinine $\mathrm{c}^{-1} \cdot 24 \mathrm{~h}^{-1}$ ) found in the children who had had diabetes for 6 years. Also shown in Figure 1 is the rising need for exogenous insulin, corresponding to the reduction in endogenous insulin.

Figure 2 shows the positive correlation $(r=0.89, p$ $<0.001$ ) between the levels of C-peptide found in the plasma and those in the urine. The variation between the values obtained from the different dilutions of urine was $5 \%$ or less, indicating that the results of dilution of urinary C-peptide are parallel to the C-peptide standard curve. When standard C-peptide was added to urine with low endogenous C-peptide values a $100 \%$ recovery was obtained.

\section{Discussion}

The major site of clearance for C-peptide is the kidney $(5.1 \mathrm{dl} / \mathrm{min}$, whereas that of insulin is $1.1 \mathrm{dl} / \mathrm{min}$ ) [11-13]. The amount of insulin found in the urine was only $0.1 \%-0.3 \%$ of the total $[11,14]$, whereas the amount of C-peptide was $5 \%$ of the total $[11,13]$. These physiological characteristics led to the development of a relatively simple method for the measurement of urinary Cpeptide for clinical use [15]. This method has a number of advantages. The urine contains virtually none of the proinsulin circulating in the plasma which can crossreact with $\mathrm{C}$-peptide antibodies to give a misleading result $[14,16]$ and furthermore, the 24 -h collection gives a better reflection of the patient's endogenous insulin production compared with a single plasma sample.

Because of the differences in methodology and expression of results, as well as the lack of proper controls in the few studies carried out on urinary C-peptide in diabetic children [7-9], there is little evidence clearly delineating the correlation between quantitative urinary C-peptide excretion and duration of the disease. In the largest series, values were expressed as total C-peptide excretion and there was a great variation in results [7]. Crossley et al. [8], who expressed their values in relation to 24 -h creatinine excretion, found a good correlation between C-peptide values and duration of the disease, but their study did not include initial values for their subjects and covered only 2 years of follow-up at the most. In the relatively small series reported by Rappaport et al. [9], the control subjects were adults.

As well as Crossley et al. [8], we found that urinary $\mathrm{C}$-peptide excretion is best expressed in relation to creatinine. Our data clearly demonstrate the progressive exhaustion of $\mathrm{B}$ cell reserves as duration of the disease lengthens and an inverse relationship with the need for exogenous insulin.

In view of the good correlation found between the plasma and urinary values of C-peptide and in view of the fact that it is simpler and less traumatic to obtain frequent urine samples from children than it is to obtain blood samples, it is felt that the determination of urinary C-peptide by the afore-described method constitutes a valuable tool in the evaluation of the diabetic child.

Additional measurements of urinary C-peptide levels in larger groups of children of varying ages, should contribute to our knowledge of the natural history of diabetes.

Acknowledgement. This investigation was supported in part by the Lea Segal Fund and a research grant from Novo Laboratories, Copenhagen, Denmark. 


\section{References}

1. Klipper J, Levinger Z, Topper E, Karp M, Laron Z (1981) Plasma C-peptide levels in juvenile diabetes. Harefuah 100: 501-504

2. Ludvigsson J, Heding LG (1978) Beta cell function in children with diabetes. Diabetes 27 (Suppl 1): 230-234

3. Ludvigsson J, Heding LG (1976) C-peptide in children with juvenile diabetes. A preliminary report. Diabetologia 12: 627-630

4. Ludvigsson J, Heding LG, Larsson Y, Leander E (1977) C-peptide in juvenile diabetics beyond the postinitial remission period. Relation to clinical manifestations at onset of diabetes, remission and diabetes control. Acta Paediat Scand 66:177-184

5. Ludvigsson J, Safwenberg J, Heding LG (1977) HLA-types, Cpeptide and insulin antibodies in juvenile diabetes. Diabetologia 13: 13-17

6. Grajwer LA, Pildes RS, Horwitz DL, Rubenstein AH (1977) Control of juvenile diabetes mellitus and its relationship to endogenous insulin secretion as measured by $\mathrm{C}$-peptide immunoreactivity. J Pediatr 90: 42-48

7. Hurter P, Zick R, Mitzkat HJ (1979) Die Bedeutung der C-Peptidebestimmung in 24 STD urine für die Behandlung diabetischer Kinder und Jugendlicher. In: Gruneklee D and Herzog W (eds) Die Bedeutung der C-Peptidebestimmung für die Diagnostik. Schnetztor Verlag, Konstanz, pp 117-125

8. Crossley JR, James AG, Eliot RB, Barryman CC, Edgar BW (1981) Residual beta cell function and islet cell antibodies in diabetic children. Pediatr Res 15: 62-65

9. Rappaport EB, Ulstrom RA, Etzwiler DD, Fife D, Hedlung BE, Steffes MW (1980) Urine C-peptide, beta cell function and insulin requirement. Am J Dis Child 134: 1129-1133
10. Heding LG (1975) Radioimmunological determination of human C-peptide in serum. Diabetologia 11: 541-548

11. Kuzuya T, Matsuda A, Sakamoto Y, Tanabshi S, Kajinuma H (1978) C-peptide immunoreactivity in urine. Diabetes 27 (Suppl 1): $210-215$

12. Faber OK, Kehlet H, Madsband S, Binder C (1978) Kinetics of human C-peptide in man. Diabetes 27 (Suppl 1): 207-209

13. Horwitz DL, Rubenstein AH, Katz AI (1977) Quantitation of human pancreatic beta cell function by immunoassay of C-peptide in urine. Diabetes $26: 30-35$

14. Constan L, Mako M, Juhn D, Rubenstein AH (1975) The excretion of proinsulin and insulin in urine. Diabetologia 11: 119-123

15. Kaneco T, Munemura M, Oka T, Suzuki H, Yasuda H, Yanaihera N, Nakagawa S, Makebe K (1975) Demonstration of C-peptide immunoreactivity in various body fluids and clinical evaluation of the determination of urinary C-peptide immunoreactivity. Endocrinol Jap 22: 207-212

16. Block MB, Mako ME, Steiner DF, Rubenstein AH (1972) Circulating C-peptide immunoreactivity. Studies in normals and diabetic patients. Diabetes 21: 1013-1026

Received: 5 February 1982

and in revised form: 1 September 1982

Professor Z. Laron

Institute of Pediatric and Adolescent Endocrinology

Beilinson Medical Center

Petah Tikva 49100, Israel 